
\title{
$\begin{array}{ll}\text { Research Square } & \begin{array}{l}\text { Preprints are preliminary reports that have not undergone peer review. } \\ \text { They should not be considered conclusive, used to inform clinical practice, } \\ \text { or referenced by the media as validated information. }\end{array}\end{array}$
}

\section{Assessment of arsenic contamination in agricultural soils of Gangetic basin in Buxar, Bhojpur and Patna districts in Bihar, India}

\section{Saurabh Kumar Pathak}

Banaras Hindu University Institute of Environment \& Sustainable Development

Munish Kumar Upadhyay

Banaras Hindu University Institute of Environment \& Sustainable Development

\section{Anurakti Shukla}

Banaras Hindu University Institute of Environment \& Sustainable Development

\section{Arnab Majumdar}

IISER-K: Indian Institute of Science Education and Research Kolkata

Sudhakar Srivastava ( $\nabla$ sudhakar.iesd@bhu.ac.in )

Banaras Hindu University https://orcid.org/0000-0001-6943-8367

\section{Research Article}

Keywords: Agricultural soil, Arsenic, Bihar, Contamination Factor, Geoaccumulation index, Incremental Lifetime Cancer Risk, Hazard Quotient

Posted Date: March 7th, 2022

DOI: https://doi.org/10.21203/rs.3.rs-1352838/v1

License: () (i) This work is licensed under a Creative Commons Attribution 4.0 International License. Read Full License 


\section{Abstract}

Arsenic (As) is a nonessential and toxic metalloid found in sediments, soils and aquatic environments. The contamination of As is a serious problem in South and Southeast Asia threatening the health of millions of people. In this study, 71 soil samples were collected from agricultural fields from Bihar, India situated in the middle Gangetic basin to understand the status of As contamination. The 71 samples from Bihar were taken from three districts; Buxar $(n=21)$, Bhojpur $(n=34)$ and Patna $(n=16)$. Arsenic concentration in soil samples was determined by the wavelength dispersive X-ray fluorescence (WD-XRF) method. The $\mathrm{pH}$, oxidation reduction potential (ORP), organic matter (OM) and cation exchange capacity (CEC) of the samples were also analysed. The mean and range of As concentration were found to be $16.72 \mathrm{mg} \mathrm{kg}^{-1}$ (13.9-19.4 $\left.\mathrm{mg} \mathrm{kg}^{-1}\right), 17.18 \mathrm{mg} \mathrm{kg}^{-1}$ (13.9$\left.21.1 \mathrm{mg} \mathrm{kg}^{-1}\right)$ and $17.16 \mathrm{mg} \mathrm{kg}^{-1}\left(14.8-20.5 \mathrm{mg} \mathrm{kg}^{-1}\right)$ in Buxar, Bhojpur and Patna, respectively. Of the 71 samples from Bihar, five samples had As levels equal to or higher than the maximum permissible limit i.e. $20 \mathrm{mg} \mathrm{kg}^{-1}$ for agricultural soil. These five samples were taken from the village of Salempur, Benwaliya, Gundi, Daulatpur and Katesar. To assess the contamination level, various indices like contamination factor, ecological risk assessment and geoaccumulation index were calculated, which indicated "moderate to high" As contamination in the studied areas. The study provides information about the As contamination scenario in middle Gangetic basin and proposes to conduct more comprehensive surveys to understand As contamination in the hugely populated state of Bihar.

\section{Introduction}

Arsenic (As) is a well-known nonessential, toxic and carcinogenic metalloid that occurs naturally in soil, aquifer and sediments. The problem of As contamination is widespread in countries like India, Bangladesh, Thailand, Taiwan, China, Argentina, Mexico, Italy, Japan, and United State of America etc. (Shaji et al. 2020; Sanjrani et al. 2019). Arsenic poisoning poses a health threat to approximately 300 million people worldwide (Srivastava et al. 2022; Kumar et al. 2021). The source of As contamination of groundwater is either geological or anthropogenic (Shukla and Srivastava 2019; Ravindra and Mor 2018). In South and Southeast Asia, natural biogeochemical processes have been the main cause of contamination of groundwater with As, however, anthropogenic impacts have made the As poisoning worse (Srivastava et al. 2022; Kumar et al. 2021). Drinking water, food and air are the major contributors of As exposure in humans (Awasthi et al. 2017; Mandal et al. 2019, Shukla et al. 2020). Rice is a major source of food in Asian countries and hence the accumulation of As in rice in this region has been marked as a serious threat (Upadhyay et al. 2019a; Yadav et al. 2021). Prolonged As exposure to humans can even cause ailments like skin, lungs, kidney and liver cancer, hyperpigmentation, and keratosis (Golui et al. 2017; Shikawa et al. 2019). The availability of As in the soil is influenced by the soil texture, $\mathrm{pH}$, organic matter, redox process, anion and cations (silicate, sulphate, nitrate) present in the soil (Mandal et al. 2019).

The Indian state of Bihar, located in the middle Gangetic basin, faces the problem of As contamination. Groundwater and soil have been found to be contaminated with As in recent studies (Shukla et al. 2020; Kumar et al. 2021). Groundwater acts as the source of drinking water for the large population of Bihar and therefore, the size of the population prone to As toxicity is also high. Before 1980s, the use of groundwater as main source of drinking water was considered safe compared to an open well. However, lately the As contamination in the states lying in Gangetic plains has increased manifold due to the increase in anthropogenic activities and consequent disturbances to natural biogeochemical processes. Out of 38 districts, people living in 22 districts of Bihar are supposed to be affected with As toxicity due to intake of contaminated groundwater (Chakraborti et al. 2018; Shukla et al. 2020; Mondal et al. 2020). Based on therecent study, the major districts of Bihar seriously affected by As are Buxar, Katihar, Lakhisarai, Saran, Vaishali, Bhojpur, Samastipur, Begusarai, Bhagalpur, Khagaria, and Munger (Kumar et al. 2021; Singh 2015). Due to groundwater contamination in Maner block of Patna, not only soil but food items have also become contaminated with As (Mandal et al. 2019; Singh and Ghosh 2012). In a recent study by Tyagi et al. (2020), significant As accumulation was reported in rice grains and rice-based food products (chuda and laiya) from Patna, Bihar and health hazards and carcinogenic risks were found to be higher than recommended safe limits. Considering the lack of survey of large parts of Bihar, the present work was planned to determine the level of As in the agricultural lands of the Gangetic plains in Bihar to get recent status of As contamination.

\section{Materials And Methods}




\section{Study area}

The present sample study was conducted in three districts: Buxar: $25^{\circ} 34^{\prime} 29^{\prime \prime} \mathrm{N}-83^{\circ} 58^{\prime} 43^{\prime \prime} \mathrm{E}$, Bhojpur: $25^{\circ} 33^{\prime} 47^{\prime \prime} \mathrm{N}-84^{\circ} 40^{\prime} 17^{\prime \prime E}$ and Patna: $25^{\circ} 36^{\prime} 8{ }^{\prime \prime} \mathrm{N} 85^{\circ} 7^{\prime} 10^{\prime \prime} \mathrm{E}$. All three districts are situated in the western part of the Bihar. This is the most fertile alluvial plain of the Ganges at an average elevation of 65 meters above sea level. These areas receive about $85 \%$ of the total rainfall ( $800-850$ $\mathrm{mm}$ ) from the southwest monsoon (ESSO/IMD, 2020). Both non-irrigated and irrigated lands are used for agriculture. Rice, wheat, gram and pulses are the main crops; vegetables are also grown abundantly in some parts.

\section{Sample collection, preparation and analysis}

The sampling was done in three different districts (Buxar, Bhojpur and Patna) of Bihar from February to March, 2020 (Figure 1). Composite soil was collected at a depth of about 5-15 cm from the surface of arable areas from fields situated close to the river bank. A composite sample (200-500 g) from each sampling site from 4-5 different points was taken. The aim was to ensure that the composite sample better represents the selected field soil. The coordinates of the sites were noted via GPS (Gramin Oregon 650). To eliminate the moisture from the collected soil samples, the soil was dried in the sun for $4-5$ days. The soil was crushed and its gravel, organic debris and small stone pieces were removed by using a $2 \mathrm{~mm}$ sieve. Soil pH, EC, and salt concentration were determined in soil suspension prepared in the ratio of 1:2 (Soil-Water) with the help of Multi-Parameter (PCSTestr ${ }^{\mathrm{TM}} 35$ OAKION UK). To find out the oxidation reduction potential (ORP) of soil, $1 \mathrm{~g}$ of soil was mixed with $10 \mathrm{ml}$ of milli-Q water and measured with the help of Aakiro Aquasol digital (AM-ORP-01) meter. The percentage of organic carbon and available phosphorus in the soil samples were determined by the rapid titration method of Wakley and Black and Oleson method.

\section{Wave Dispersive X-ray Fluorescence}

WDXRF (Wave Dispersive X-ray Fluorescence) (S8 Tiger, Bruker, Mannheim, Germany) method was used for elemental detection. The press pellet method was used for the analysis of As (Upadhyay et al. 2021). In the press pellet method, $1 \mathrm{~g}$ of boric acid powder was mixed with $4 \mathrm{~g}$ of dried and sieved soil sample in a homogeneous manner. Round pellet form of soil samples was formed with the help of the $\mathrm{KBr}$ (potassium bromide) press pellet machine. Analysis of these round pellet forms of samples in XRF analyzer was done by X-ray beam with the help of existing automatic detector. To ensure qualitative accuracy, standard reference materials (SRMs) and blanks were handled alongside the samples and were analysed in triplicates as per the details given in Upadhyay et al. (2021).

\section{Risk assessment indices}

\section{Contamination factor (CF)}

The contamination factor has been widely used in many previous studies to determine the metal contamination level at the soil surface (Jiang et al. 2018; Li et al. 2018a; Li et al. 2018b). CF is the ratio of the concentration of each metal in the soil to the background value or baseline value of that metal in soil and it is calculated by the given formula:

$\mathrm{CF}=\left(\mathrm{C}_{\mathrm{HM}} / \mathrm{C}_{\mathrm{BV}}\right)$

where $\mathrm{C}_{\mathrm{HM}}$ and $\mathrm{C}_{\mathrm{BV}}$ indicate heavy metals concentration in soil and reference value/ background value of heavy metal in soil respectively. The reference value for As was taken as $6.83 \mathrm{mg} \mathrm{kg}^{-1}$ (Rinklebe et al. 2019). According to CF value, contamination level may be classified as low $(0>C F<1)$, moderate $(1 \leqq C F<3)$, considerable $(3 \leqq C F<6)$ and very high $(C F>6)$.

\section{Potential ecological risk assessment}

The potential ecological risk (PER) index based on the heavy metal concentration, sensitivity, toxicity, type and reference value was proposed by Håkanson (1980). The risk index was used in this study to estimate the ecological hazards of HMs present in the soil. The formulas are as follows:

$\mathrm{C}_{\mathrm{f}}=\mathrm{CF}=\left(\mathrm{C}_{\mathrm{HM}} / \mathrm{C}_{\mathrm{BV}}\right)$ 
$E_{r}=T_{r} * C_{f}$

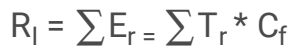

Where the method of computing $\mathrm{C}_{\mathrm{f}}$ is exactly the same as that of CF (see Eq. (1)), $\mathrm{E}_{\mathrm{r}}$ represents monomial potential ecological risk factor and $\mathrm{HM}$ toxic response factor is denoted by $\mathrm{T}_{\mathrm{r}}(\mathrm{Hg}=40, \mathrm{As}=10, \mathrm{Cd}=30, \mathrm{Cu}=5, \mathrm{~Pb}=5, \mathrm{Ni}=5, \mathrm{Cr}=2, \mathrm{Zn=1})(\mathrm{Wang}$ et al. 2018). As per PER, ecological risk can be categorized as low $\left(E_{r} \leq 40\right)$, moderate $\left(40<E_{r} \leq 80\right)$, considerable $\left(80<E_{r} \leq 160\right)$, high $\left(160<\mathrm{E}_{\mathrm{r}} \leq 320\right)$ and very high $\left(320<\mathrm{E}_{\mathrm{r}}\right)$.

\section{Geo-accumulation index $\left(\mathrm{I}_{\text {geo }}\right)$}

The soil accumulation index was calculated using the formula developed by Müller (1969), which reports the extent of metal contamination in the soil (Kormoker et al. 2019; Islam et al. 2020).

$\mathrm{I}_{\mathrm{geo}}=\log _{2}\left(\mathrm{C}_{\mathrm{m}} / 1.5 \mathrm{~B}_{\mathrm{m}}\right)$

In the above equation, $\mathrm{Cm}$ is the concentration of the metal in the present soil sample and Bm is the background value of the same metal. The factor 1.5 has been used with reference to possible variations in the background value. For the classification of various degrees of contamination level, total 7 classes the geo-accumulation index was reported.

\begin{tabular}{|ll|}
\hline Values & Classes/Grades \\
\hline $\mathrm{I}_{\mathrm{geo}}<0$ & Class 0 (nearly uncontaminated): \\
\hline $0<\mathrm{I}_{\mathrm{geo}}<1$ & Class 1 (uncontaminated to moderately contaminated) \\
\hline $1<\mathrm{I}_{\mathrm{geo}}<2$ & Class 2 (moderately contaminated) \\
\hline $2<\mathrm{I}_{\mathrm{geo}}<3$ & Class 3 (moderately to severely contaminated) \\
\hline $3<\mathrm{I}_{\mathrm{geo}}<4$ & Class 4 (severely contaminated) \\
\hline $4<\mathrm{I}_{\mathrm{geo}}<5$ & Class 5 (severely to extremely contaminated) \\
\hline $5<\mathrm{I}_{\mathrm{geo}}$ & Class 6 (extremely contaminated) \\
\hline
\end{tabular}

\section{Health risk assessment}

Oral intake is very important for the entry of As into the human body among ingestion, oral intake, dermal contact and inhalation. In this study, the As non-carcinogenic risk assessment was done based on the average daily dose (ADD) and hazard quotient (HQ) through soil only (Masood et al. 2019).

$A D D=(E P C \times I R \times E D \times E F) /(B W \times A T)$

EPC used in the formula denotes exposure point concentration $\left(\mathrm{mg} \mathrm{kg}^{-1}\right)$ in soil, ED exposure duration (assumed 70 years), EF

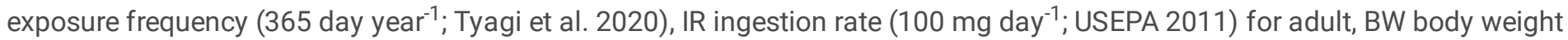
(70 Kg; (USEPA 2005) and AT average period of exposure (25,550 days; Masood et al. 2019) respectively. An exposed population is considered at risk when HQ is greater than one (Masood et al. 2019; Shahid et al. 2017).

The ratio of $A D D$ and $R_{f} D$ represents the hazard quotient (Masood et al. 2019; Shahid et al. 2017).

$\mathrm{HQ}=\mathrm{ADD} / \mathrm{R}_{\mathrm{f}} \mathrm{D}$ 
where $R_{f} D$ is representing the reference dose $\left(\mathrm{mg} \mathrm{kg}^{-1} \mathrm{~d}^{-1}\right)$. The maximum permissible exposure to the human population is estimated through daily exposures taking into account the vulnerable groups during the lifetime. For $A s, R_{f} D$ is considered as $0.0003 \mathrm{mg} \mathrm{kg}^{-1} \mathrm{~d}^{-1}$ (Tyagi et al. 2020).

The carcinogenic health risk was assessed as Incremental Lifetime Cancer Risk (ILCR) by following (Tyagi et al. 2020). Using the mean As concentration in soil, the ILCR was calculated by using the following formula.

$\mathrm{ILCR}=\mathrm{ADD} \times \mathrm{SF} \ldots \ldots \ldots . .(8)$

SF is considered as slope factor. The SF is considered as 1.5 for As (USEPA 2017). As per USEPA (2001), the ILCR between $10^{-6}$ to $10^{-4}$ is considered to be within the safe limit.

\section{Statistical analysis}

Statistical Package for the Social Sciences for Windows (SPSS) version 16.0 and Microsoft Office Excel Version 16.0 (Microsoft Corporation, Washington, USA) was used in the study for correlation analysis. To determine significance in all tests significance level of 0.01 was used. Maximum, minimum, standard error, mean and median values were calculated. One-way ANOVA and Tukey tests were performed to measure how significantly the averages As content of samples collected from different regions differed from each other.

\section{Results And Discussion}

The aquifers of West Bengal and Bangladesh are considered to be As contaminated. The distribution of contaminated aquifers and the level of As in these aquifers is a variable phenomenon (Fendorf et al. 2010). It is known that the large amount of water is required to irrigate the paddy crop, as a result of which As is also continuously added in the paddy soil and As accumulates in the rice plants and grains through the soil (Shrivastava et al. 2014). Arsenic mobility in the soil is dependent on the soil physicochemical parameters (Upadhyay et al. 2019b). The physical and chemical characteristics of the soil samples are shown in Table 1. Based on the obtained results, the soil samples of the selected sites were mildly alkaline with $\mathrm{pH} 7.48 \pm 0.5$. The average soil organic matter (\%OM) content was found to be 1.18 in Buxar, 1.56 in Bhojpur and 1.97 in Patna soil sample. Thus, after analyzing 71 soil samples from all three districts, a correlation was found between pH and soil organic matter (Fig. 2). In the case of $\mathrm{pH}$ and ORP, the average $\mathrm{pH}$ was lowest for Patna samples and the maximum for Buxar samples, while the average ORP was highest for Patna samples, followed by Bhojpur and Buxar samples. Based on this result, an inverse relationship could be established between pH and ORP (Fig. 2). The average ORP was 248.86, 254.85 and $282.06 \mathrm{mV}$ for Buxar, Bhojpur and Patna respectively. The average cation exchange capacity of samples from three districts was $16.3,17.78$ and 12.39 meq per $100 \mathrm{~g}$ of soil, respectively. In this study, the average As concentration in 21 soil samples of Buxar, 34 from Bhojpur and 16 from Patna in Bihar state was $16.72 \mathrm{mg} \mathrm{kg}^{-1}\left(13.9-19.4 \mathrm{mg} \mathrm{kg}^{-1}\right), 17.18 \mathrm{mg} \mathrm{kg}^{-1}\left(13.9-21.1 \mathrm{mg} \mathrm{kg}^{-1}\right), 17.16 \mathrm{mg} \mathrm{kg}^{-1}\left(14.8-20.5 \mathrm{mg} \mathrm{kg}^{-1}\right)$ respectively (Fig. 3).

Table 1: Mean, minimum, maximum values, standard deviation and coefficient of variation (\%) of various physicochemical parameters of soil. 


\begin{tabular}{|c|c|c|c|c|c|c|c|c|c|c|}
\hline Areas & & $\mathrm{pH}$ & $\begin{array}{l}\mathrm{OC} \\
(\%)\end{array}$ & $\begin{array}{l}\mathrm{OM} \\
(\%)\end{array}$ & $\mathrm{ORP}(\mathrm{mV})$ & $\begin{array}{l}\text { CEC } \\
\text { (meq/ } \\
100 \mathrm{~g})\end{array}$ & $\begin{array}{l}\mathrm{EC}(\mu \mathrm{S} \\
\left.\mathrm{cm}^{-1}\right)\end{array}$ & $\begin{array}{l}\text { Salt (mg kg- } \\
\left.{ }^{1}\right)\end{array}$ & $\begin{array}{l}\text { As } \\
(\mathrm{mg} \\
\left.\mathrm{kg}^{-1}\right)\end{array}$ & $\begin{array}{l}\text { Avl P } \\
\left(\mathrm{kg} \mathrm{h}^{-}\right. \\
\left.{ }^{1}\right)\end{array}$ \\
\hline \multirow{5}{*}{$\begin{array}{l}\text { Buxar } \\
\text { (Bihar) } \\
(\mathrm{N}=21)\end{array}$} & Mean $\pm S D$ & $7.6 \pm$ & \multirow{2}{*}{$\begin{array}{l}0.68 \pm \\
0.34\end{array}$} & \multirow{2}{*}{$\begin{array}{l}1.18 \pm \\
0.59\end{array}$} & \multirow[t]{2}{*}{$248.86 \pm 28.7$} & $16.73 \pm$ & \multirow{2}{*}{$\begin{array}{l}183.81 \pm \\
51.55\end{array}$} & \multirow[t]{2}{*}{$74.09 \pm 24.00$} & \multirow{2}{*}{$\begin{array}{l}16.72 \pm \\
1.62\end{array}$} & \multirow{2}{*}{$\begin{array}{l}38.88 \pm \\
16.68\end{array}$} \\
\hline & & 0.55 & & & & 6.09 & & & & \\
\hline & Minimum & 6.22 & 0.18 & 0.32 & 211 & 0.39 & 88.7 & 51.2 & 13.9 & 6.94 \\
\hline & Maximum & 8.23 & 1.46 & 2.53 & 316 & 20.50 & 296 & 128 & 19.4 & 82.79 \\
\hline & $\mathrm{CV}(\%)$ & 7.24 & 50 & 50 & 11.53 & 36.41 & 28.05 & 32.39 & 9.69 & 42.90 \\
\hline \multirow{4}{*}{$\begin{array}{l}\text { Bhojpur } \\
\text { (Bihar) } \\
(\mathrm{N}=34)\end{array}$} & Mean $\pm S D$ & $\begin{array}{l}7.46 \pm \\
0.53\end{array}$ & $\begin{array}{l}0.90 \pm \\
0.42\end{array}$ & $\begin{array}{l}1.56 \pm \\
0.72\end{array}$ & $254.85 \pm 21.15$ & $\begin{array}{l}17.78 \pm \\
6.34\end{array}$ & $\begin{array}{l}160.03 \pm \\
60.28\end{array}$ & $65.52 \pm 16.36$ & $\begin{array}{l}17.18 \pm \\
1.8\end{array}$ & $\begin{array}{l}47.57 \pm \\
25.50\end{array}$ \\
\hline & Minimum & 6.4 & 0.18 & 0.31 & 213 & 0.16 & 65.2 & 39.1 & 13.9 & 18.39 \\
\hline & Maximum & 8.62 & 2.19 & 3.8 & 303 & 20.51 & 292 & 105 & 21.1 & 122.76 \\
\hline & CV(\%) & 7.1 & 46.01 & 46.01 & 8.30 & 35.90 & 37.67 & 26.16 & 10.48 & 53.61 \\
\hline \multirow{4}{*}{$\begin{array}{l}\text { Patna } \\
(\text { Bihar) } \\
(\mathrm{N}=16)\end{array}$} & Mean $\pm S D$ & $\begin{array}{l}7.38 \pm \\
0.29\end{array}$ & $\begin{array}{l}1.14 \pm \\
0.52\end{array}$ & $\begin{array}{l}1.97 \pm \\
0.9\end{array}$ & $282.06 \pm 25.73$ & $\begin{array}{l}12.39 \pm \\
9.03\end{array}$ & $\begin{array}{l}170.8 \pm \\
51.24\end{array}$ & $70.49 \pm 27.04$ & $\begin{array}{l}17.16 \pm \\
1.74\end{array}$ & $\begin{array}{l}67.13 \pm \\
35.52\end{array}$ \\
\hline & Minimum & 6.97 & 0.18 & 0.31 & 233 & 0.31 & 94.2 & 48.1 & 14.8 & 15.11 \\
\hline & Maximum & 7.78 & 2.29 & 3.97 & 320 & 20.55 & 261 & 90.1 & 20.5 & 135.64 \\
\hline & CV (\%) & 3.93 & 45.98 & 45.98 & 9.12 & 43.94 & 30 & 38.36 & 10.14 & 52.91 \\
\hline
\end{tabular}

The maximum permissible limit of As content for agricultural soil recommended by the European Union is $20 \mathrm{mg} \mathrm{kg}^{-1}$. The globally acceptable average As concentration for soil is $10 \mathrm{mg} \mathrm{kg}^{-1}$ (Rahaman et al. 2013). The results obtained from the present study revealed that the level of arsenic contamination in none of the 21 samples from Buxar district exceeded the permissible limits of agricultural land. The 3 sample of Bhojpur and 2 sample of Patna had As contamination levels more than $20 \mathrm{mg} \mathrm{kg}^{-1}$. These 5 samples taken from the village of Salempur, Benwaliya, Gundi, Daulatpur and Katesar in Bihar had As concentration of $20.4 \mathrm{mg} \mathrm{kg}^{-1}, 20 \mathrm{mg} \mathrm{kg}^{-1}, 21.1 \mathrm{mg} \mathrm{kg}^{-1}, 20.4 \mathrm{mg} \mathrm{kg}^{-1}$ and $20.5 \mathrm{mg} \mathrm{kg}^{-1}$, respectively (Fig. 3). The coefficient of variation (CV\%) of As ranged from 9 to $11 \%$ for Buxar, Bhojpur and Patna. The CF values were between 2 to 3 for 69 out of 71 samples, which showed moderate contamination in soil. One sample of Bhojpur and one from Patna had CF value equal to 3 , which indicates considerable contamination level (Fig. 4A). Er value for Buxar, Bhojpur, and Patna was below 40 (20.35-30.89) indicating low risk (Fig. 4B). In order to find out the contamination level in agricultural land at different locations, geo-accumulation index was devised. I geo was 0.44-1.04, 0.44-0.92 and 0.53-1.00 in samples obtained from Bhojpur, Buxar and Patna in Bihar, respectively (Fig. 4C). Therefore, on the basis of $\mathrm{I}_{\text {geo, }}$, the soil samples showed moderate contamination. The values of Er, CF and $\mathrm{I}_{\text {geo }}$ are given in supplementary file 1.

It is well known As-soil geochemistry, such as bioavailability and mobility of As, depends on the soil redox state. The important properties of soil, pH, ORP and organic matter affect the absorption/desorption of As (Wang and Mulligan 2006; Barla et al. 2017). In this study, interpolation was done by using Inverse Distance Weighting (IDW) technique to determine the distribution of metal and organic matter at the sampling site, and how soil pH and ORP are related to As distribution. However, there was no direct association of As concentration with $\mathrm{pH}, \mathrm{ORP}$ and $\mathrm{OM} \%$. The variability of As levels within a field, region or a large area is a complex phenomenon depending on the relationship with soil pH, ORP and OM (Anwar et al. 2013; Barla et al. 2017). Arsenic adsorption in silt-clay soils declines $\geq \mathrm{pH} 7$ while in an acidic environment, As adsorption is greater (Strawn 2018; Gersztyn et al. 2013). Further, soil pH and ORP appear to have an adverse effect on the bioavailability and mobility of As (Barla et al. 2017). Cation exchange capacity is a very important physical and chemical factor for agricultural soil. Soil organic matter, soil pH, soil fertility, and the availability of nutrients in the soil to plants all have a significant relationship with cation exchange capacity. CEC 
not only reflects the properties of the soil surface, but it is also an indicator of fertilizer supply capacity in the soil, transport and breakdown of pollutants in the soil (Yunan et al. 2018). The maximum mean CEC was found for the sample of Bhojpur while the lowest for the Patna sample. ADD, HQ and ILCR were also calculated for Buxar, Bhojpur and Patna soil sample. All the values are

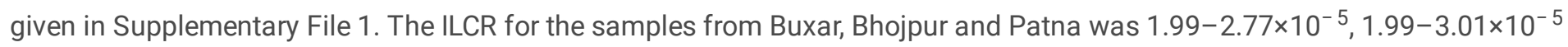
and $2.11-2.93 \times 10^{-5}$, respectively. Similarly, the average HQ was $0.080,0.082$ and 0.082 for Buxar, Bhojpur and Patna, respectively. The obtained results showed that the samples from 3 districts had $\mathrm{HQ}$ values less than one for As which was not a threat in the exposed population. The value of ILCR ranged from $10^{-6}-10^{-4}$, which was well within the safe limits proposed by the USEPA 2001.

\section{Conclusion}

In conclusion, the present study highlighted moderate As contamination in studied districts. Further, there were no noncarcinogenic and carcinogenic risks reported. However, the study proposes regular monitoring of the areas considering the increasing As contamination in Gangetic plains of India. The sampling area in this study is primarily agricultural land, therefore, regular monitoring of groundwater which is a main source of irrigation, should also be done for As content. There are two sampling sites in Bhojpur and Patna, having CF values equivalent to 3, indicating a high As contamination load. Therefore, the Gangetic basin in Bihar needs regular monitoring and control measures to prevent this problem from turning into uncontrollable havoc.

\section{Declarations}

\section{Authors Contributions}

SKP performed all the experiments and analyzed the data along with the statistical analysis. MKU and AM, performed WDXRF experiments and analyzed the data. AS prepared the draft of the MS. SS supervised the whole experiment and finalized the draft for submission.

\section{Funding}

This research was supported by a research grant from ASEAN-India S \& T Development Fund (AISTDF), Department of Science and Technology, India (IMRC/AISTDF/CRD/2018/000072). Saurabh Pathak is thankful to AISTDF for Junior Research Fellowship (JRF) in the project.

\section{Availability of data and materials}

The data that support the findings of this study are available from the corresponding author upon reasonable request.

\section{Ethics approval and consent to participate}

Not applicable

\section{Consent for publication}

Not applicable (This study did not contain any individual person's data in any form).

\section{Competing Interests}

The authors declare no conflict of interest.

\section{References}

1. Allison LE (1965) Organic Carbon. In: Methods of Soil Analysis. Part II. In: Black C.A. (ed.). American Society of Agronomy, pp. $1367-1376$ 
2. Anwar-Mohamed A, El-Sherbeni A, Kim SH, Elshenawy OH, Althurwi HN, Zordoky BN, El-Kadi AO (2013) Acute arsenic treatment alters cytochrome P450 expression and arachidonic acid metabolism in lung, liver and kidney of C57BI/6 mice. Xenobiotica 43:719-729. https://doi.org/10.3109/00498254.2012.754113

3. Awasthi S, Chauhan R, Srivastava S, Tripathi RD (2017) The Journey of Arsenic from Soil to Grain in Rice. Front Plant Sci 8:1007. https://doi.org/10.3389/fpls.2017.01007

4. Barla A, Shrivastava A, Majumdar A, Upadhyay MK, Bose S (2017) Heavy metal dispersion in water saturated and water unsaturated soil of Bengal delta region, India. Chemosphere 168:807-816. doi: 10.1016/j.chemosphere.2016.10.132

5. Chakraborti D, Singh SK, Rahman MM, Dutta RN, Mukherjee SC, Pati S et al (2018) Groundwater arsenic contamination in the Ganga River basin: a future health danger. Int J Environ Res Public Health 15:180. https://doi.org/10.3390/ijerph15020180

6. ESSO/IMD/RainfallVariability/04 (2020)/28. https://imdpune.gov.in/hydrology/rainfall\%20variability\%20page/bihar_final.pdf. accessed 12 January 2022

7. Fendorf S, Michael HA, Van Geen A (2010) Spatial and temporal variations of groundwater arsenic in South and Southeast Asia. Science 328:1123-1127. https://www.science.org/doi/ 10.1126/science.1172974

8. Gersztyn L, Karczewska A, Gałka B (2013) Influence of pH on the solubility of arsenic in heavily contaminated soils. Environ Prot Nat Resour 3:7-11. https://doi.org/10.2478/oszn-2013-0031

9. Golui D, Guha Mazumder DN, Sanyal SK, Datta SP, Ray P, Patra PK, Sarkar S, Bhattacharya K (2017) Safe limit of arsenic in soil in relation to dietary exposure of arsenicosis patients from Malda district, West Bengal- A case study. Ecotoxicol Environ Saf 144:227-235. https://doi.org/10.1016/j.ecoenv.2017.06.027

10. Håkanson L (1980) An ecological risk index for aquatic pollution control: a sediment ecological approach. Water Res 14:975-1001

11. Hassan M (2018) As in Groundwater: Poisoning and Risk Assessment. CRC Press, Boca Raton. https://doi.org/10.1201/9781315117034

12. Islam MS, Ahmed MK, Al-Mamun MH, Eaton DW (2020) Human and ecological risks of metals in soils under different land use in an urban environment of Bangladesh. Pedosphere 30:1-12. https://doi.org/10.1016/S1002-0160(17)60473-9

13. Jiang QT, He JY, Ye GQ, Christakos G (2018) Heavy metal contamination assessment of surface sediments of the East Zhejiang coastal area during 2012-2015. Ecotoxicol Environ Saf 163:444-455.

https://doi.org/10.1016/j.ecoenv.2018.07.107

14. Kormoker T, Proshad R, Islam S, Ahmed S, Chandra K, Uddin M, Rahman M (2019) Toxic metals in agricultural soils near the industrial areas of Bangladesh: ecological and human health risk assessment. Toxin Rev 40:1135-1154. https://doi.org/10.1080/15569543.2019.1650777

15. Kumar A, Ali M, Kumar R, Kumar M, Sagar P, Pandey RK, Akhouri V, Kumar V, Anand G, Niraj PK, Rani R, Kumar S, Kumar D, Bishwapriya A, Ghosh AK (2021) Arsenic exposure in Indo Gangetic plains of Bihar causing increased cancer risk. Sci Rep 11:2376. https://doi.org/10.1038/s41598-021-81579-9

16. Kumar A, Rahman MS, Iqubal MA, Ali M, Niraj PK, Anand G, Kumar P (2016) Ground water arsenic contamination: a local survey in India. Int J Prev Med 7:100. doi: 10.4103/2008-7802.188085

17. Li HJ, Gao XL, Gu YB, Wang RR, Xie PF, Liang M, Ming HX, Su J (2018a) Comprehensive large-scale investigation and assessment of trace metal in the coastal sediments of Bohai Sea. Mar Pollut Bull 129:126-134. https://doi.org/10.1016/j.marpolbul.2018.02.022

18. Li QF, Zhang YQ, Lu YL, Wang P, Suriyanarayanan S, Meng J, Zhou YQ, Liang RY, Khan K (2018b) Risk ranking of environmental contaminants in Xiaoqing River, a heavily polluted river along urbanizing Bohai rim. Chemosphere 204:28-35. https://doi.org/10.1016/j.chemosphere.2018.04.030

19. Mandal J, Golui D, Datta PS (2019) Assessing equilibria of organo-arsenic complexes and predicting uptake of arsenic by wheat grain from organic matter amended soils. Chemosphere 234:419-426. https://doi.org/10.1016/j.chemosphere.2019.06.088

20. Mandal J, Golui D, Raj A, Ganguly P (2019) Risk assessment of arsenic in wheat and maize grown in organic matter amended soils of Indo-Gangetic plain of Bihar, India. Soil Sediment Contam 28:757-772. 
https://doi.org/10.1080/15320383.2019.1661353

21. Masood N, Farooqi A, Zafar MI (2019) Health risk assessment of arsenic and other potentially toxic elements in drinking water from an industrial zone of Gujrat, Pakistan: a case study. Environ Monit Assess 191:95.

https://doi.org/10.1007/s10661-019-7223-8

22. Mondal D, Rahman MM, Suman S et al (2021) Arsenic exposure from food exceeds that from drinking water in endemic area of Bihar, India. Sci Total Environ 754:142082. https://doi.org/10.1016/j.scitotenv.2020.142082

23. Podgorski JE, Eqani SAMAS, Khanam T, Ullah R, Shen H, Berg M (2017) Extensive arsenic contamination in high-pH unconfined aquifers in the Indus Valley. Sci Adv 3:e1700935. https://doi.org/10.1126/ sciadv.1700935

24. Ranjan RK, Sinha AK, Gupta D, Sappal SM, Kumar A, Ramanathan AL (2016) Sedimentary geochemistry of Kabar Tal wetland, Begusarai, Bihar, India. J Appl Geochem 18:414-429

25. Ravindra K, Mor S (2019) Distribution and health risk assessment of As and selecteheavy metals in Groundwater of Chandigarh, India. Environ Pollut 250:820-830

26. Rinklebe J, Antoniadis V, Shaheen SM, Rosche O, Altermann M (2019) Health risk assessment of potentially toxic elements in soils along the Central Elbe River, Germany. Environ Int 126:76-88. https://doi.org/10.1016/j.envint.2019.02.011

27. Sanjrani MA, Zhou B, Zhao H, Bhutto SA, Muneer AS, Xia SB (2019) Arsenic contaminated groundwater in China and its treatment options, a review. Appl Ecol Environ Res 17:1655-1683. http://doi.org/10.15666/aeer/1702_16551683

28. Shahid M, Khalid M, Dumat C, Khalid S, Niazi NK, Imran M, Tabassum RA (2017) Arsenic level and risk assessment of groundwater in Vehari, Punjab Province, Pakistan. Expos Health 10:229-239. http://doi.org/10.1007s/12403-017-0257-7

29. Shaji E, Santosh M, Sarath KV, Prakash P, Deepchand V, Divya BV (2021) Arsenic contamination of groundwater: A global synopsis with focus on the Indian Peninsula. Geosci Front 12:101079. https://doi.org/10.1016/j.gsf.2020.08.015

30. Shikawa S, Arao T, Makino T (2019) Agronomic strategies for reducing arsenic risk in rice. In: Yamauchi H, Sun G (eds) Arsenic Contamination in Asia. Springer, Singapore, pp 181-198. https://doi.org/10.3389/fsufs.2020.00053.

31. Shrivastava A, Barla A, Yadav H, Bose S (2014) Arsenic contamination in shallow groundwater and agricultural soil of Chakdaha block, West Bengal, India. Front Environ Sci 2:50. https://doi.org/10.3389/fenvs.2014.00050

32. Shukla A, Awasthi S, Chauhan R, Srivastava S (2020) The status of arsenic contamination in India. In: Srivastava S (ed) Arsenic in Drinking Water and Food. Springer, Singapore, pp 1-12. doi: 10.1007/978-981-13-8587-2_1.

33. Shukla A, Srivastava S (2019) A review of phytoremediation prospects for arsenic contaminated water and soil. In: Bauddh VC (ed) Phytomanagement of polluted sites: Market opportunities in sustainable phytoremediation, Pandey. Elsevier, Netherlands, pp 243-254. doi: 10.1016/B978-0-12-813912-7.00008-9.

34. Singh SK, Ghosh AK (2012) Health risk assessment due to groundwater arsenic contamination: Children are at high risk. Hum Ecol Risk Assess 18:751-766

35. Singh SK, Ghosh AK, Kumar A, Kislay K, Kumar C, Tiwari RR, Imam MD (2014) Groundwater arsenic contamination and associated health risks in Bihar. India. Int J Environ Res 8:49-60. doi.10.22059/IJER.2014.693

36. Srivastava S, Pathak S, Ponsin M, Hensawang S, Chanpiwat P, Yoeurn C, Phan K (2022) Sustainable solutions to arsenic accumulation in rice grown in south and south-east. Asia Crop Pasture Sci 73:149-159. doi: 10.1071/CP21033

37. Strawn DG (2018) Review of interactions between phosphorus and arsenic in soils from four case studies. Geochem Trans 19:10. doi: 10.1186/s12932-018-0055-6

38. Tyagi N, Raghuvanshi R, Upadhyay MK, Srivastava AK, Suprasanna P, Srivastava S (2020) Elemental (As, Zn, Fe and Cu) analysis and health risk assessment of rice grains and rice based food products collected from markets from different cities of Gangetic basin, India. J Food Compost Anal 93:103612

39. Upadhyay MK, Majumdar A, Barla A, Bose S, Srivastava S (2019a) An assessment of arsenic hazard in groundwater-soil-rice system in two villages of Nadia district, West Bengal, India. Environ Geochem Health 41:2381-2395. doi: 10.1007/s10653019-00289-4

40. Upadhyay MK, Majumdar A, Barla A, Bose S, Srivastava S (2021) Thiourea supplementation mediated reduction of grain arsenic in rice (Oryza sativa L.) cultivars: A two year field study. J Hazard Mater 407:124368. doi:

10.1016/j.jhazmat.2020.124368

Page $9 / 11$ 
41. Upadhyay MK, Shukla A, Yadav P, Srivastava S (2019b) A review of arsenic in crops, vegetables, animals and food products. Food Chem 276:608-618. doi: 10.1016/j.foodchem.2018.10.069

42. USEPA (2001) Risk assessment guidance for Superfund: volume III - part A, process for conducting probabilistic risk assessment. EPA 540-R-02-002. US Environmental Protection Agency, Washington, D.C.

43. USEPA (2005) Human Health Risk Assessment Protocol for Hazardous Waste Combustion Facilities. Office of Solid Waste, United States Environmental Protection Agency530-R-05-006

44. USEPA (2011) Exposure Factors Handbook (Final Report). U.S. Environmental Protection Agency, Washington, DC. EPA/600/R-09/052F

45. USEPA (2017) Secondary drinking water standards: Guidance for nuisance chemicals. In Drinking Water ContaminantsStandards and Regulations EPA 822-F-18-001

46. Wang H, Wu Q, Hu W, Huang B, Dong L, Liu G (2018) Using multi-medium factors analysis to assess heavy metal health risks along the Yangtze River in Nanjing, Southeast China. Environ Pollut 243(Pt B):1047-1056. doi:

10.1016/j.envpol.2018.09.036

47. Wang S, Mulligan CN (2006) Effect of natural organic matter on arsenic release from soils and sediments into groundwater. Environ Geochem Health 28:197-214. doi: 10.1007/s10653-005-9032-y

48. Yunan D, Xianliang Q, Xiaochen W (2018) Study on cation exchange capacity of agricultural soils. In: IOP Conference Series: Mater Sci Eng 392:042039

\section{Figures}

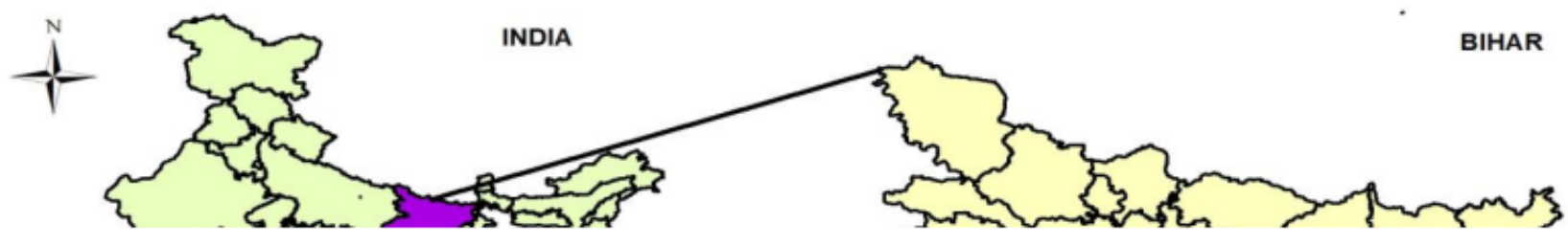

\section{Figure 1}

Geographical location of the study area (Buxar, Bhojpur and Patna in Bihar) chosen as sampling site in the middle Gangetic basin for collection of soil samples. 
Spatial distribution of arsenic in soils and physical characteristics of soils samples collected from Buxar, Bhojpur and Patna districts of Bihar.

\section{Figure 3}

Arsenic concentration $\left(\mathrm{mg} \mathrm{kg}^{-1}\right)$ in soil samples collected from agricultural field located in middle Gangetic basin in Bihar. All values are mean of triplicates \pm S.D. One way ANOVA significant at $p \leq 0.01$. Different letters indicate significant differences between As concentration of various sample.

\section{Figure 4}

Box plot showing the contamination factors (CFs) (A), potential ecological risk factors (PER) (B), and geoaccumulation index (C) of arsenic in soils at different sampling location.

\section{Supplementary Files}

This is a list of supplementary files associated with this preprint. Click to download.

- SupplementaryFile1.xlsx 